\title{
Showcasing the Tourism Potentials of Lokoja, Kogi State, Nigeria
}

\author{
Stella 0. Ebiloma \\ Kogi State University, Anyigba, Nigeria \\ Email: ebilomastella@gmail.com
}

How to cite this paper: Ebiloma, S.O. (2019) Showcasing the Tourism Potentials of Lokoja, Kogi State, Nigeria. Open Journal of Social Sciences, 7, 318-332. https://doi.org/10.4236/jss.2019.77027

Received: April 25, 2019

Accepted: July 26, 2019

Published: July 29, 2019

Copyright $\odot 2019$ by author(s) and Scientific Research Publishing Inc. This work is licensed under the Creative Commons Attribution International License (CC BY 4.0).

http://creativecommons.org/licenses/by/4.0/

\section{c) (i) Open Access}

\begin{abstract}
Kogi State is one of the 36 states of the Federal Republic of Nigeria with Lokoja as the capital. Objective of the Study: To quantify the tourism potentials (abiotic and biotic) of some tourism sites in Lokoja, because information is needed for tourism development, marketing and promotion. Instruments Used: Surveying tape, Global Positioning system (GPS), Prismatic compass clinometers, appropriate books for vegetation identification, writing materials for noting field observations and a digital camera. Data collection involved stock assessment, direct measurements (quantitative) of the tourism resources on sites including their qualitative assessment. Results obtained are GPS readings of Latitudes and Longitudes in degrees and minutes, Elevations in metres, Bearing in degrees, Length and Breadth, Height of buildings and wall thickness in metres and vegetation identification. Tourism resources at the sites were also recorded. These tourists' attractions (heritage, relics) are unique and are not available anywhere else in the world.
\end{abstract}

\section{Keywords}

Kogi State, Lokoja, Lord Lugard, Tourism Resources

\section{Introduction}

The needs of tourists are different thus, serving tourists is dynamic. Few people understand tourism and what is required to develop successful tourism products. A community's resources are its culture; traditions, shops, leisure facilities, etc. They represent the core resource base for tourism. Tourism use of tourist resources, both natural and cultural, should be non-consumptive, so that they are always available [1].

Tourism represents one of the few economic opportunities available to remote communities. It provides real opportunities to reduce unemployment and create 
employment for disadvantaged people and stimulate development. Tourism has proven to revitalize cultures and traditions. Tourism can provide an economic incentive to conserve natural and cultural assets. Tourism has been shown to foster greater understanding between peoples and a greater global consciousness [2]. Kogi State is one of the 36 states of the Federal Republic of Nigeria. It is reputed as the museum of Nigerian colonial history, as enumerated thus. NATURAL LAND FEATURES: RIVERS: Among the rivers in Kogi State are the largest rivers in West Africa, rivers Benue and Niger [3]. River Benue with its source from one of the Cameroon Mountains and river Niger, one of the longest rivers in the world, with its source at Futa Djallon plateau on the borders of Sierra Leone and the Gulf of Guinea converge in Lokoja, forming a Y-shaped confluence called Niger/Benue confluence. The confluence flows southwards into the Sea. This confluence was discovered by the Lander brothers in 1830. At the peak of the dry season, the Confluence Island can accommodate over 10,000 holidaymakers. It is a beautiful attraction for carnivals, picnics, wedding receptions, crusades etc. [3]. Flora Shaw was said to have coined the name 'Nigeria' (Niger-area) from the top of this mount while viewing river Niger, when she was working as a foreign journalist during the colonial era. She later got married to Lord Lugard [3]. MOUNTAINS: Mount Patti. Patti is a Nupe word for hill. It has a height of about $458.3 \mathrm{~m}$ above sea level and about $33 \mathrm{~m}$ above the level of the Niger valley. It is about $15 \mathrm{~km}^{2}$ square at the top. From here it is possible to view the scenic plain surrounding Lokoja and the silent grandeur and beautiful nature of the confluence. On this mountain are located: Lord Lugard's rest house, Nigeria Telecommunication (NITEL), Nigeria Television Authority (NTA), and Grace FM station. Ajaokuta steel company can be viewed from the top of this mountain. It has a terrific driveway to the top [3]. Caves: The Usikokoko cave in Konto-Karfe was a security abode for thousands of people in the Igu Kingdom during intertribal wars of those days. The cave which has three openings can be viewed easily on Lokoja-Abuja high way. The rock bridge at Egane in Igala land is a massive piece of naturally occurring rock under which flows the Maboro River. The rock serves as a natural bridge over the river for the transportation of vehicular and human traffic.

PLATEAUX: Agbaja plateau: About $14 \mathrm{~km}$ from Lokoja is a town situated on top of a plateau. It is about $355.8 \mathrm{~m}$ above sea level. It has shrub/grassland vegetation with a climate comparable to that experienced on Jos plateau. Ogidi: is a town with formations of Igneous Rock Mountains and a traditional art and craft industry [3].

HISTORICAL MONUMENTS: The Inikpi statue (Plate 1) is located at Ega in the heart of Idah market in Idah Local Government Area of the State. Heroine Inikpi was a beloved daughter of Attah Igala (Ayegba, the $4^{\text {th }}$ ). She willingly gave herself up to be buried alive in order to save the Igala Kingdom from enemy forces during inter-tribal war with the Jukuns. The Iron of liberty (Plate 2): Lokoja was a prominent root in the then colonial British Empire, due to its loca- 
tion near the bank of river Niger in the $18^{\text {th }}$ and $19^{\text {th }}$ centuries. It also became a collection centre for slaves seized from slave merchants. From here, they were subsequently set free. The freedom spor was marked with an iron pole tagged the "Iron of liberty". Bishop Samuel Ajayi Crowther spearheaded that anti-slavery crusade. The iron of liberty is presently within the compound of Crowther Holy Trinity School. CENOTAPH: Is a monument built in memory of the dead but not containing the remains of the dead [4] The World War Cenotaph (Plates 3-5) in Lokoja was erected in remembrance of the fallen heroes of the Nigerian, British officers and other ranks who fought in the first and second world wars of 1914, 1918 and 1939-1945. It is located along Muritala Mohammed way Lokoja. A copy of the Cannon used by the British forces in both East Africa and Cameroon against the German forces in defence of their occupied territories, during the "scramble for Africa", is seen mounted on the Cenotaph. Government functionaries and Nigerian soldiers in Kogi State mark the yearly army remembrance day in this place. On the concrete block, names of the soldiers who fought in the two world wars are seen written on a plaque. Concrete pillar (Plate 6). After the Government closed its consulate in Lokoja in 1866, the Royal Niger Company was formed in 1882 to administer Lokoja. This was revoked on the $31^{\text {st }}$ of December 1899 . On the $1^{\text {st }}$ of January 1900 , the British Government assumed direct control and the protectorate of Northern Nigeria was declared over Northern Nigeria, with Lord Fredrick Lugard as the High Commissioner [5].

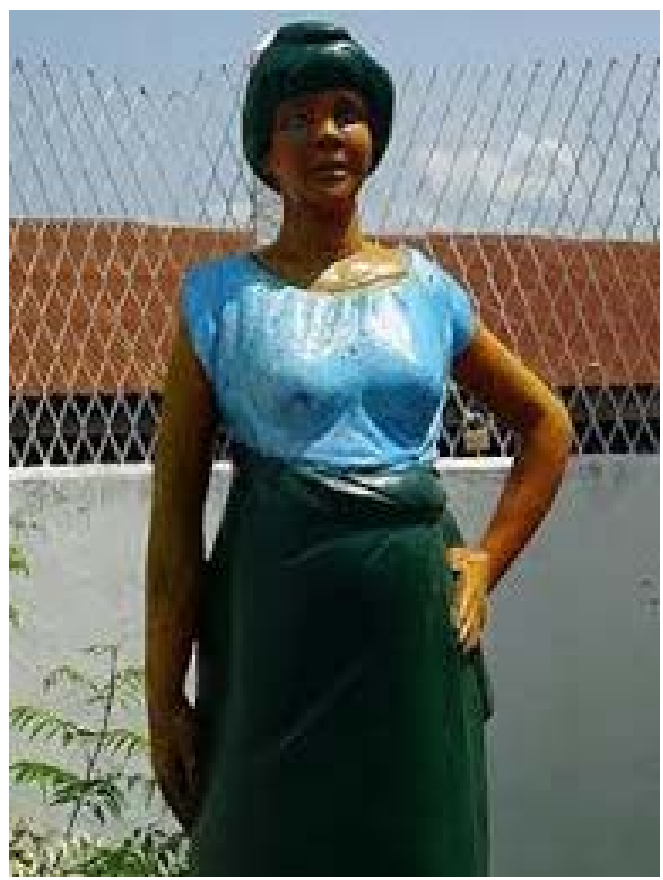

Plate 1. Princess Inikpi of the Igala people. Source:

https://www.google.com/search?q=image+of+inikpi+statue\&tbm=isch\&s ource=univ\&client=firefox-b-d\&sa=X\&ved=2ahUKEwjppZTR7rHiAhX$\underline{\text { RBUIHUguDkAQ7Al6BAgJEA8\&biw }=1366 \& \text { bih }=654 \# \text { imgrc }=\text {. }}$ 


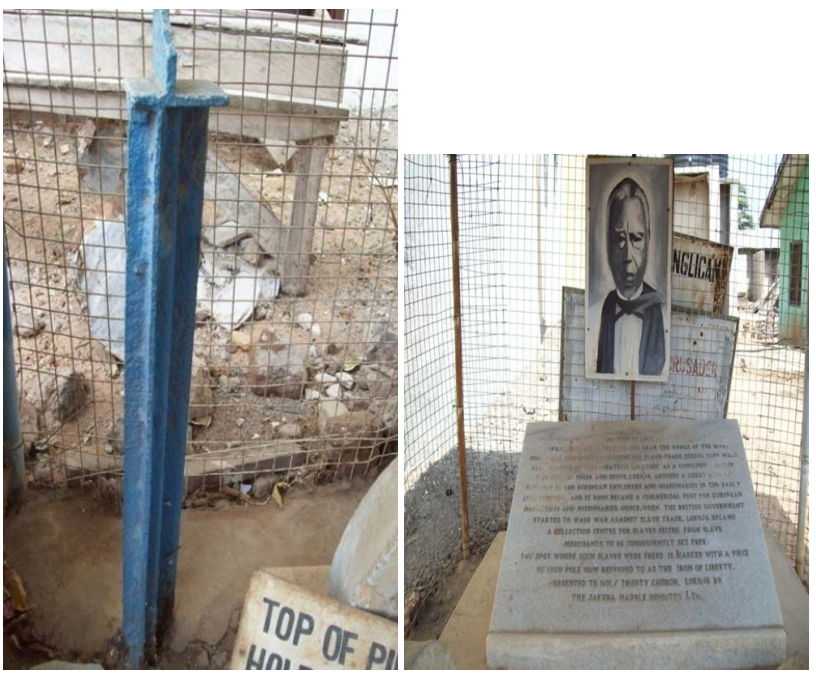

Plate 2. Iron of Liberty and the write up enclosed with the Iron of Liberty. Source: field survey.

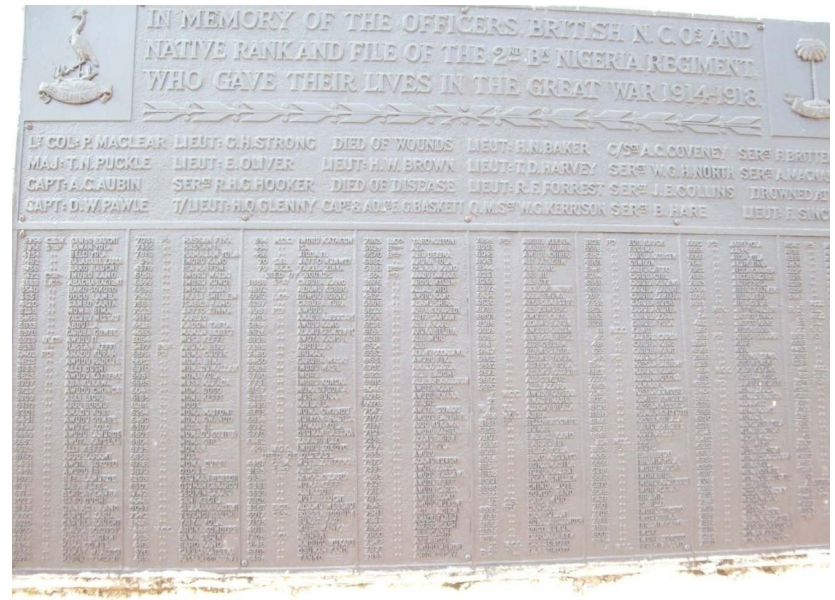

Plate 3. Officers of Nigeria regiment in 1914-1918 World War 1 inscribed on a plaque on the Cenotaph. Source: field survey.

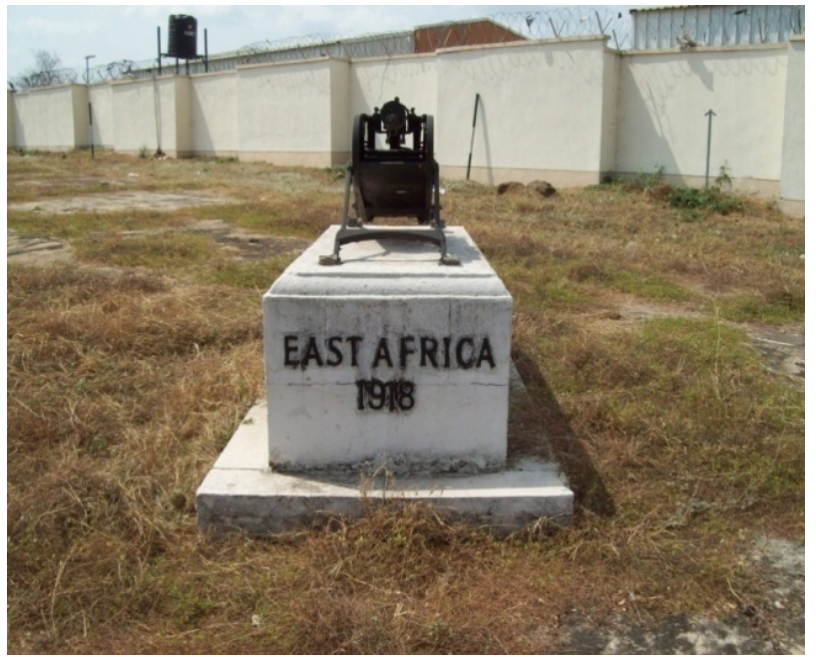

Plate 4. Artillery used 1918. Source: Field survey. 


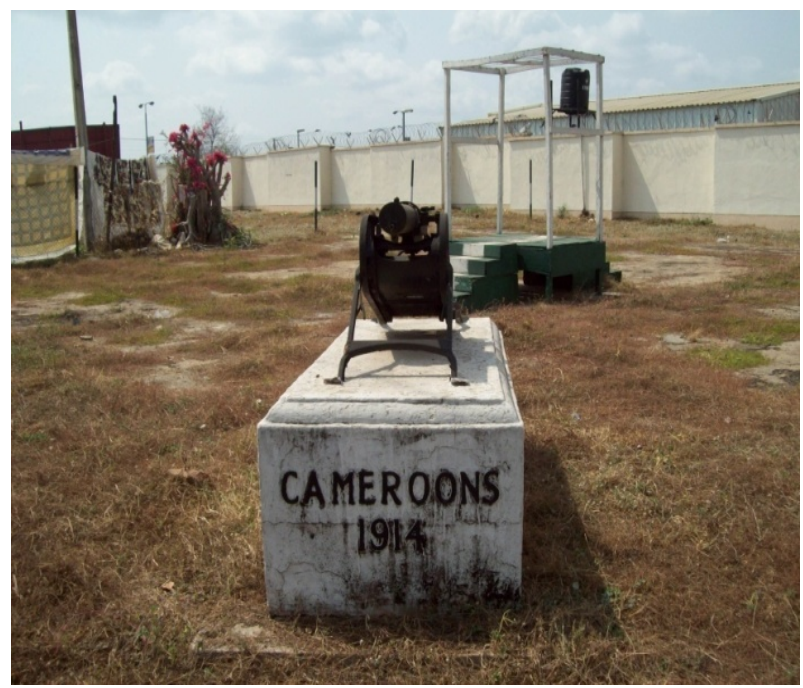

Plate 5. Artillery used in Cameroon in 1914. Source: field survey.
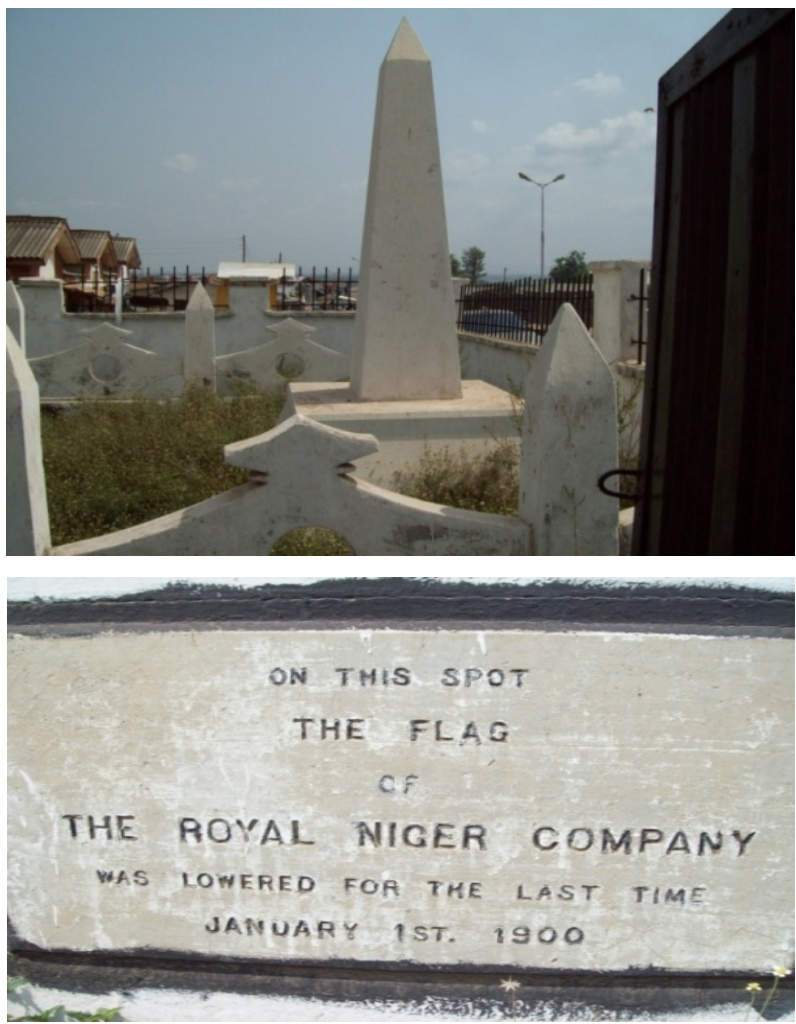

Plate 6. Concrete pillar of British Government-Lokoja, Karaworo area Lokoja. Source: field survey,

The spot of the formal handing over of administration and control of Lokoja was marked with a concrete pillar measuring $2.5 \mathrm{~m}$ high. It was here that the royal Niger Company flag was lowered for the last time in Nigeria and the Union Jack of the British Government was hoisted.

HISTORICAL RELICS: Lord F.J.D. Lugard's office and residence (1901), is now Kogi State Government House. The first primary school in Northern Ni- 
geria, the Crowther Holy Trinity primary school was founded 1865 in Lokoja through the efforts of early Christians such as late Bishop Ajayi Crowther and one pastor John. Burial ground of Bishop Ajayi Crowther is located within the premises of the school. Magazine hill in Lokoja, a store house for military ammunitions by the Royal Niger Company and African Frontier forces, it has also served as a police station and as a jail yard for accused persons from the native town. Bank treasury of the first ever conventional bank in Northern Nigeria, the Anglo African Bank (Lugard bank), established in 1905. United African Trading Company (U.A.C). Constructed warehouses for the import and export of their goods and vacated them in 1963. The first military church in Northern Nigeria, built of burnt bricks in 1905, located along Muritala Mohammed road, Lokoja. The first prison yard in Northern Nigeria. Lord Lugard's senior staff quarters (five of them). One of which currently accommodates The Kogi State tourism board, Lokoja (Plate 7). These were and still are prefabricated buildings from Britain. They were assembled without using nails and mounted on stilts at different locations in Lokoja, one of which now accommodates the Kogi State Hotels and Tourism Board, Lokoja. Egbunu Akoko's residence, Ajaokuta steel complex, a traditionalist who forecasted the siting of the steel company before his death. His ancient house has resulted in the breakdown of all the mechanically fit bulldozers that have attempted its demolition. The first hospital in Northern Nigeria (1900), now being occupied by the Kogi State Council for Arts and Culture, Lokoja.

Recreational facilities are found in some hotels, like the multi-million naira, confluence beach hotel with its Olympic size swimming pool in addition to other modern recreational facilities. Altogether, there are about 175 hotels and restaurants scattered around the various local Government areas of the State. However according to Jumia Travels [6], there are 83 hotels in Lokoja alone,

Cultural attractions such as the Akodi African Centre and Colourful cultural festivals or events. There are about 31 cultural festivals in Kogi State.

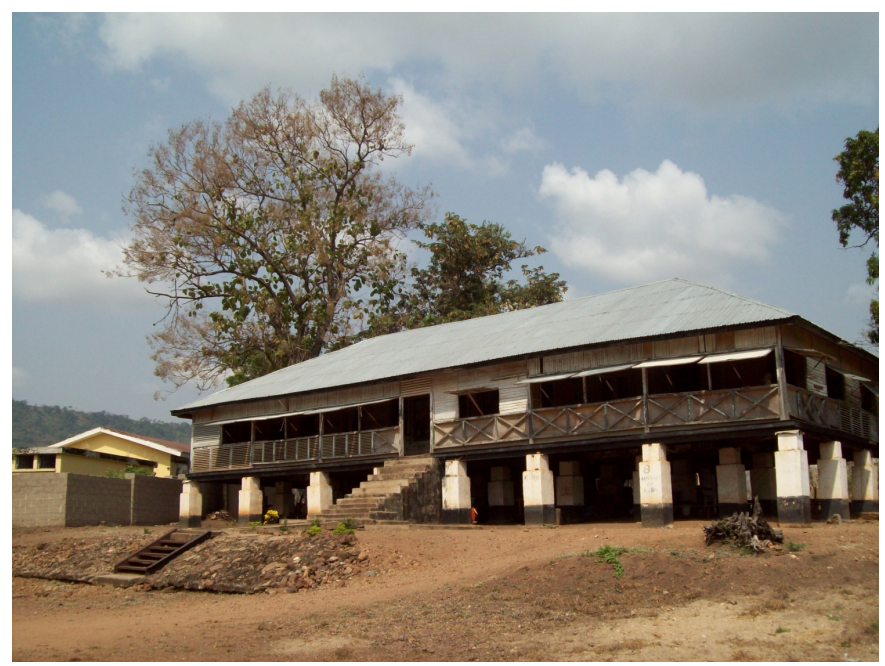

Plate 7. Kogi state tourism board accommodation. Source: field survey. 
Lokoja is the capital of Kogi State, it has a wealth of tourist resources (natural and historical relics) lying fallow, which, with proper organisation, packaging, presentation for tourist enjoyment and marketing, will diversify and strengthen the economic base of the State, both Government and citizens, improve the aesthetic value of the environment, conserve the gene pool within the State and generate gainful employment opportunities for the teaming unemployed. It will open up new business horizons to potential entrepreneurs and open up the state to the influx of the international community, thus attracting foreign investors for the benefit of earning foreign exchange by the state. This will result in revenue and wealth generation; improve the standard of living of the citizenry through well-developed sustainable tourism. Thus converting conservation areas in Lokoja into money spinning tourism centers with attractions comparable to those sought after anywhere in the world.

The objective of the study was to quantify the tourism potentials (abiotic and biotic) of some tourism sites in Lokoja Local Government Area of Kogi State.

\section{Methodology}

\subsection{Study Area}

Lokoja is a city in Nigeria (Figure 1). It lies at the confluence of the Niger and Benue rivers. It is the 4th biggest city in Kogi and is the capital of Kogi State (Figure 2). The straight distance between Lokoja and Abuja is 101 miles (162 kilometres). The city accommodates a population of 60,579. Weather records are as follows: Temperature is $85^{\circ} \mathrm{F}\left(29^{\circ} \mathrm{C}\right)$, Wind Speed at $4 \mathrm{mph}(6 \mathrm{~km} / \mathrm{h})$ and $67 \%$ Humidity. Latitude is $7^{\circ} 47^{\prime} 48.77^{\prime \prime} \mathrm{N}$ while Longitude is $6^{\circ} 44^{\prime} 25.73^{\prime \prime} \mathrm{E}$ [7] with an altitude 45 to 125 metres above sea level. It is situated on the western bank of the River Niger close to its confluence with River Benue and sandwiched between the River and the Mount Patti [8].

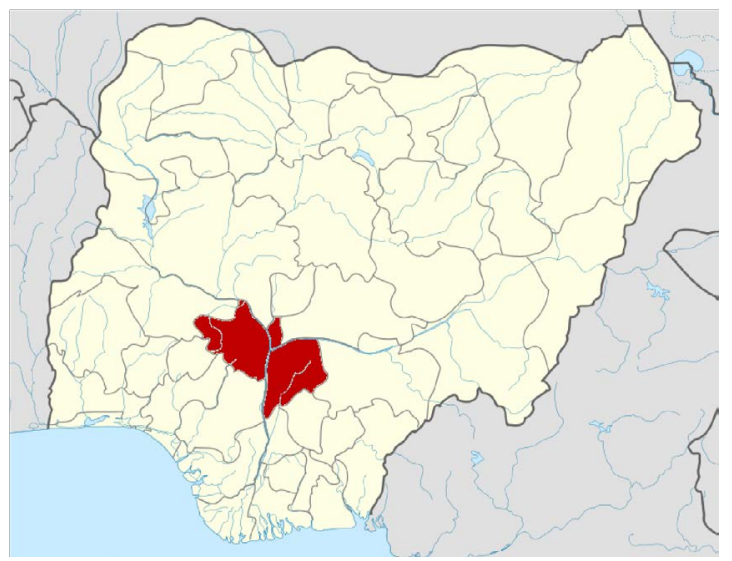

Figure 1. Map of Nigeria showing Kogi State. Source: https://www.google.com/search?q=map+of + Kogi+state+showing+lokoja\&cli ent=firefox-b-d\&tbm=isch\&source=iu\&ictx=1\&fir=CPiLq6fjFYIwMM\%253 A\%252C7uVCUGHgr0RjEM\%252C_\&vet=1\&usg=AI4_-kQKfuss5R-REBIos ZIw95iyFzTzfA\&sa=X\&ved=2ahUKEwjF1vzA2NXiAhUUShUIHeTYAa8Q9 QEwBHoECAQQDA\#imgrc=FmUdJqiCFDS29M:\&vet=1. 


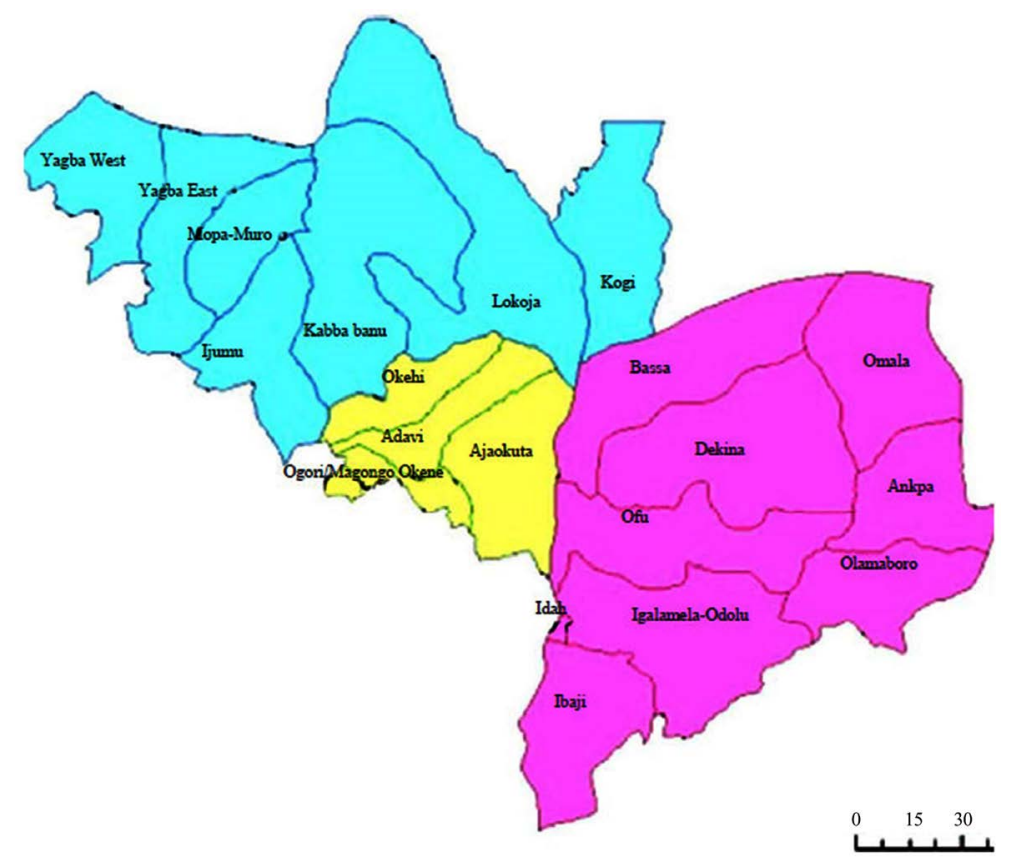

Figure 2. Map of Kogi State showing the position of Lokoja. Source: https://www.google.com/search?client=firefox-b-d\&biw=1366\&bih=654\&tbm =isch\&sa=1\&ei=lkszXYyuN_qh1fAPjt-3sAs\&q=journal+articles+of+kogi+stat e+showing+lokoja\&oq=journal+articles+of+kogi+state+showing+lokoja\&gs_1 =img.3...114478.117648..119848...0.0..0.736.4234.3-2j2j3j1.....0....1..gws-wiz-im g.vCMIbm0TFhg\&ved=0ahUKEwiM0Z2h_8PjAhX6UBUIHY7vDbYQ4dUDC $\underline{\text { AY\&uact }=5 \# \text { imgdii }=\text { cVS5-OEVaIdAPM:\&imgrc }=\text { QXfVFVKp-j499M: }}$

There are many tourist attractions scattered around Kogi state, purposive sampling technique, (a type of non-probability sampling) was used to make the choice of the sites chosen since there is a high concentration of them within the same Local Government area and tourists usually want to see so much within a short period of time.

\subsection{The Tourism Sites for This Study}

1) The tourism board of Kogi State-Lokoja (Plate 7)

2) The cenotaph-Lokoja

3) The iron of liberty-Lokoja

4) Concrete pillar of British Government-Lokoja

5) European/African missionaries and soldiers Cemeteries in three locations-Lokoja

6) Lord Lugard's Bank Safe-Lokoja

7) Lord Lugard's colonial two room rest house on mount Patti-Lokoja

\subsection{Data Collection}

This involved quantifying and taking direct measurements of the tourism resources available on the study sites including their qualitative assessment i.e. whether sites are neat or unkempt, attractive or unattractive, maintained or in 
disrepair etc.

Vegetation identification was with the aid of important plant identification books such as "Some changes and corrections ..." [9]. The useful plants of West tropical Africa [10], Flora of West African trees volume 1 part one and two and volume 2 [11], A handbook of West African weeds [12]. The flora of Nigeria: grasses [13], Traditional medicine and Pharmacopoeia [14].

Instruments employed in the course of the study include: surveying tape, Global Positioning System (GPS), appropriate books for vegetation identification, writing material for noting field observations and a digital camera.

\section{The following data were collected at the tourism sites}

1) Measurements of length, breadth and heights were obtained using the surveying tape.

2) Coordinates of sites were obtained using the Global Positioning system (GPS).

3) Identification of trees and shrubs present were carried out using appropriate materials.

4) Taking note of other tourism potentials such as portraits, tourism videos with their associated electronic facilities, artilleries and names on the Plaque at the Cenotaph, names and the causes of death of those buried at the European/African missionaries and soldiers Cemeteries in three locations-Lokoja.

5) Assessment of the maintenance of sites; whether the sites are well kept or unkempt, messy and neglected, attractive or unattractive, in disrepair, lawn situation and whether place is in need of a face lift or beautification etc.

6) Assessment of state of monuments-first conventional bank in northern Nigeria, Cenotaph, Concrete Pillar of British Government, Iron of Liberty and its enclosure, etc.

\section{Results}

\subsection{Tourism Potentials of Lugard's Bank Safe Building (LOKOJA)}

GPS readings: Lat. N07 $48^{\prime} 36.6^{\prime \prime}$, long. E006 $44^{\prime} 45.96^{\prime \prime}$, elev. $60 \mathrm{~m}$; compass bearing: $21^{\circ} \mathrm{NE}-210^{\circ} \mathrm{SW}$; Length $-2.50 \mathrm{~m}$, Breadth $-1.823 \mathrm{~m}$ and Height of the building: $-3.5 \mathrm{~m}$ high while the Wall of the building is $0.83 \mathrm{~m}$ thick.

The treasury (Bank safe) inside Lugard's bank: GPS readings: Length: -0.98 $\mathrm{m}$, Breadth: $-0.50 \mathrm{~m}$, depth: $-0.54 \mathrm{~m}$.

\subsection{The World War Cenotaph}

GPS readings: lat. $\mathrm{NO}^{\circ} 47^{\prime} 93.7^{\prime \prime}$, long. E006 $44^{\prime} 67.9^{\prime \prime}$, elev. 70 m; Breadth-21.09 $\mathrm{m}$, Length-66.20 $\mathrm{m}$.

Attractions inside the cenotaph are; A plaque on which are inscribed the names, official numbers, titles and causes of death of 387 Officers of Nigeria regiment who gave their lives in 1914-1918 World War 1, four artilleries and a podium used annually, during Army remembrance day were at the World War Cenotaph. 


\subsection{Concrete pillar of British Government}

GPS readings: Lat. N07 $48^{\prime} 38.7^{\prime \prime}$, long. E006 $38.5^{\prime}$, elev. $74 \mathrm{~m}$; Compass bearing: $40^{\circ} \mathrm{NE}-220^{\circ} \mathrm{SW}$.

The fence: Length-5.30 m, Breadth-5.0 m; Base of pillar: Length and Breadth $1.2 \mathrm{~m}$ by $1.2 \mathrm{~m}$ and I.0 m high. While height of pillar was $2.6 \mathrm{~m}$ Lokoja.

On this spot the flag of the Royal Niger Company was lowered for the last time on January $1^{\text {st }} 1900$.

Situation report: With the successive visits to this place since the inception of this study, the structure, fence and gate have been observed to be in good conditions even the white paint.

Iron of Liberty: GPS readings: lat: NO7 ${ }^{\circ} 48^{\prime} 51.1^{\prime \prime}$, long E006 $44^{\prime} 47.5^{\prime \prime}$ elev 65 m; Compass bearing: $40^{\circ} \mathrm{NE}-209^{\circ} \mathrm{SW}$; Length and breadth of the enclosure: -3.12 $\mathrm{m} \times 2.51 \mathrm{~m}$. The Iron of Liberty is $1.4 \mathrm{~m}$ long.

Message enclosed with "The Iron of Liberty" and the portrait of Bishop Samuel Ajayi Crowther: Lokoja, because of its location near the banks of river Niger, it was an important centre for slave trade during Nupe wars. Also because of the strategic location as a confluence of the two rivers-Niger and Benue, Lokoja aroused a great deal of interest for the European explorers and missionaries in the early $19^{\text {th }}$ century and it soon became a commercial post for European merchants and missionaries. Hence when the British government started to wage war against slave trade, Lokoja became a collection centre for slaves seized from slave merchants to be consequently set free, the spot where such slaves were freed is marked with a piece of iron pole now referred to as the Iron of Liberty presented to Holy Trinity church, Lokoja, (Jakusa Marble Industry, LTD).

\subsection{Lugard's Colonial Rest House, Situated on Top of Mount Patti (Plate 8)}

GPS reading: N-07²6'15.7", E-007²4'41.11", Elevation-301.3 m; Door measurements: Length $-2.2 \mathrm{~m}$, breadth $-1.1 \mathrm{~m}$; Window measurement: Length -1.7 $\mathrm{m}$, Width $-1.3 \mathrm{~m}$; Floor: length $-4.3 \mathrm{~m}$, width $-4.3 \mathrm{~m}$; Height of the building without roof: $2.3 \mathrm{~m}$; Total length of the house: $8.6 \mathrm{~m}$.

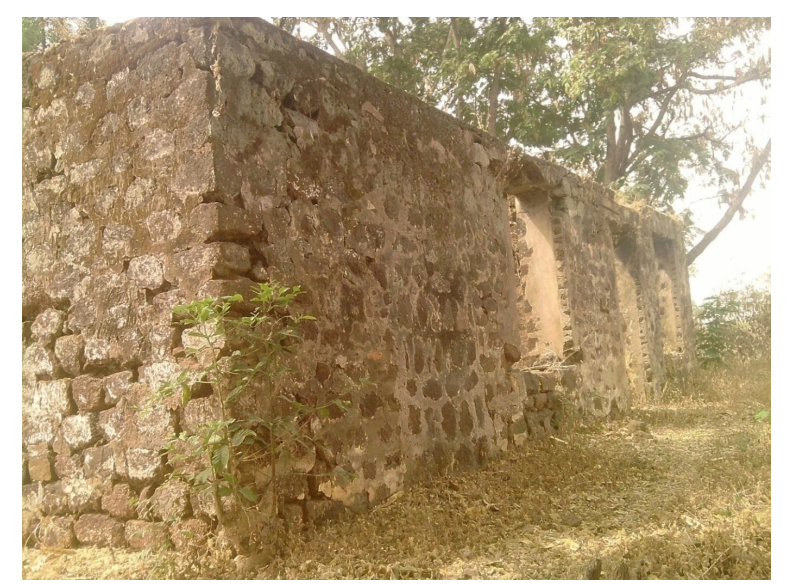

Plate 8. Lugard's colonial two room rest house on Mount Patti. 


\subsection{The Three European Cemeteries, Lokoja}

The GPS readings, Compass bearings, sizes, number of tombs, name of plants, name of author of plants, vegetation types and number of each plant are presented in Table 1.

Four of the best tombs in these cemeteries were constructed by some European tourists who visited and saw the tombs of their relatives and paid a company to erect the four tombs.

\subsection{Kogi State Tourism Board Building}

GPS readings: Lat. N07, $48^{\prime} 15.2^{\prime \prime}$, Long. E006 ${ }^{\circ} 44^{\prime} 23.9^{\prime \prime}$, Elev. 73 m; Compass bearing: $40^{\circ} \mathrm{NE}-220^{\circ} \mathrm{SW}$; Building: Length: $-200 \mathrm{~m}$, Breath: $-5.4 \mathrm{~m}$; this office is the first point of call for anyone who enters the state with tourism in mind. This is because the place serves the trio purpose of; Tour booking office, the place where tourists are assigned tour guides and tour commencement and termination point. Tourism resources at the board include; A unique building which was erected in 1900; A chain used for holding boat at the river bank; A conference hall with a comfortable capacity of twenty people; A variety of tourism videos with the associated necessary electronic facilities for the viewing pleasure of tourists; Portraits-Of lord Lugard, Bishop Ajayi Crowther, proposed upgrading of Kogi Hotel, Lokoja, the aeral perspective, Echane masquerade in Ibira land, trasission of ivias (young virgin) into womanhood at Ogorimagongo, Pottery making in Yagba west Local Government Area, the spot where Royal Niger company flag was lowered in 1900, Ibira cloth weaving in Okene Local Government Area, one of the Lord Lugard's senior staff quarters, The first primary school in Northern Nigeria built in 1854, Inikpi statue at Idah, Idah Local Government area, Alhaji Labaran Audu, former chairman, Kogi Hotels and Tourism Board, June 1992 February 1994, members of board of directors of Kogi Hotels and tourism Board, Dr. Andrew Eniola, former general manager, Kogi

Table 1. The three European cemeteries, Lokoja. Location and inventory of the three European cemeteries, Lokoja.

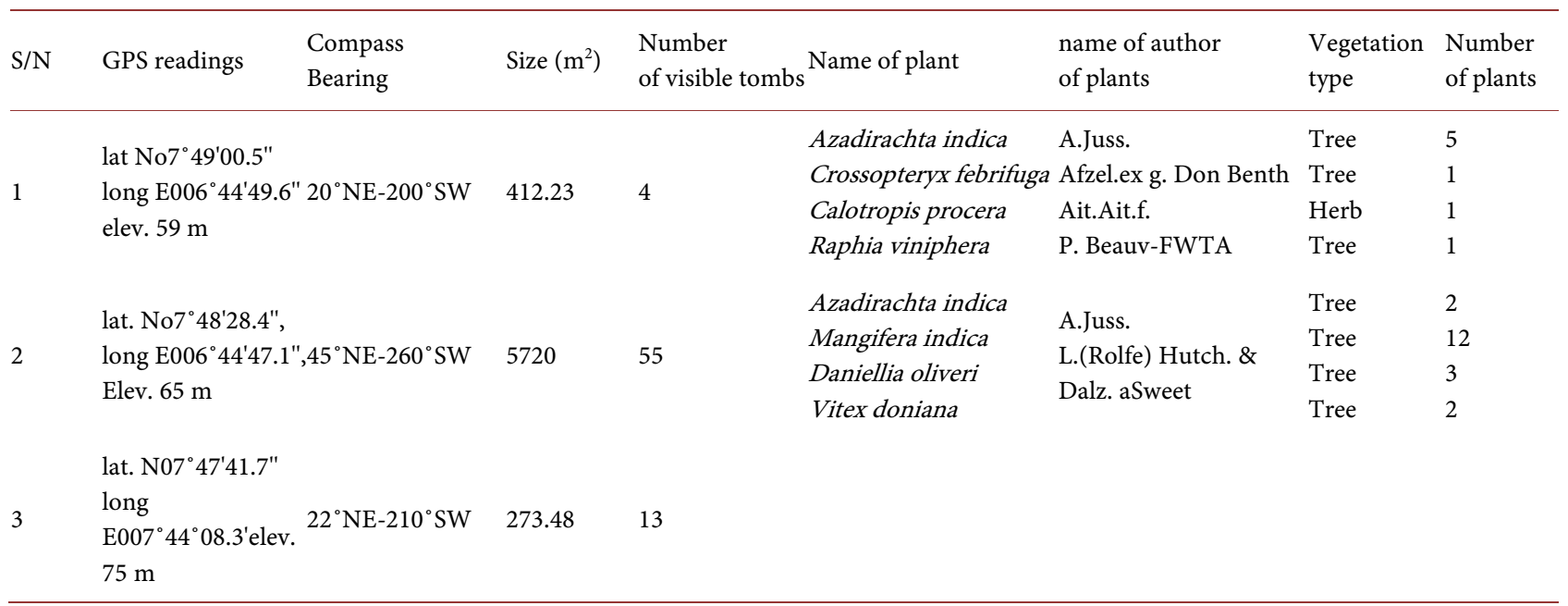


Hotels and tourism Board, January 1992, aeriel view of Lokoja from Mount Patti, Dr. Namdi Azikiwe, Major General Yakubu Gowon (head of Nigeria military government and commander-in-chief of the Armed Forces, General Ibrahim Babangida, CFR Fss Mnimni, president, and commander-in-chief of the Armed Forces, Federal Republic of Nigeria, General Sani Abacha, GCON. Head of state and commander-in-chief of the Armed Forces, Federal Republic of Nigeria, Olusegun Obasonjo, GCFR, president, Federal Republic of Nigeria, General abdulsalami A. Abubakar, Head of state and commander-in-chief of the Armed Forces, Federal Republic of Nigeria, Col. Danladi M. Zakari, Military administrator, Kogi State of Nigeria, September 1, 1991-January 2, 1992, His Excellency, Prince Abubakar Audu, First executive governor of Kogi State, January 2, 1992-November 17, 1003, Col. Omeruo FSS MSS (+), Military administrator, Kogi State of Nigeria, Col. Bzigu Lassa Afakiriya. FSS MSS PSC, Military administrator, Kogi State of Nigeria, Col. Austine U, Aniebo. FSS MSS PSS (+), Military administrator of Kogi State of Nigeria, Our Excellencies, Alhaji Ibrahim Idris, Alhaji Idris Wada and Alhaji Yahaya Adoza Bello the executive governors of Kogi State.

\section{Discussion}

Some of the tourism resources floated by Kogi State Tourism Board, Lokoja are similar to what obtains in the tourism centres of some places outside Nigeria such as the tourists' attraction of South Carolina [15]. Lokoja has an abundance of natural and man-made tourist resources which include its rich and lush vegetation, its natural formations of hills and rocks, Mount Patti with its dangerous driveway to the top and massive stones. In addition to springs are the Y-shaped confluence of Rivers Niger and Benue which join at Lokoja the state capital, sighting of the point where the two rivers meet tends to be very ecstatic and breathtaking, cruising on the confluence in boats and live jackets, Museums, Historical monuments and relics, recreational facilities (Stadia), catering establishments and hotels/motels and interesting events.

The Etowah County Tourism Board's office is also taken as a tourist attraction as reported by Powell [16]. Kogi State Tourism Board is also one of the tourist attractions of Lokoja, one of the houses that dates back to the colonial era. The mission of most state department offices of tourism is to promote vacationing in the state by residents and visitors and to contribute to the state's economy by supporting the state's tourism industry, which also obtains in Kogi State Tourism Board. The Board also provides: maps of the state, makes tourism related suggestions to all kinds of visitors, including families, individual, corporate and adventure seekers when needed, information about state scenic drives, guides to special-purpose travel, such as fishing, cruising on the river Niger/Benue confluence, provides links to accommodations, restaurants and shopping centres. The office also has the calendar of local festivals and events, has magazines featuring photographs and articles of Kogi state history and possesses printed 
guides and literature, current weather and Photo gallery. All these are available at Kogi State Tourism Board, Lokoja at no extra cost.

Lokoja has enjoyed the privileged visits of up to 36 ambassadors who visited the state for the purpose of tourism.

The artefacts found in Kogi State Cenotaph were all fabricated in Kogi State by the Ministry of Culture and tourism and mounted at the present site from inception; it has never had a temporary site (Field survey). The Cenotaph also accommodates a podium which is used by the Governor yearly during Army Remembrance Day every $15^{\text {th }}$ of every January [17]. Both local and international tourists visit the place. The monument has about 371 names inscribed on a Plaque. They are the names of the Native rank and file of the $2^{\text {nd }}$ Nigeria regiment and the British C.Os who gave their lives in the Great World War 1 of 1914-1918 and second world war of 1930-1945. The courses of the death of some of the officers are indicated alongside the names on the plaque. The courses of death included; wounds, drowned at sea, died of disease and accidentally killed. Cenotaph is from the Greek word meaning; 'empty tomb. It is a tomb or public monument built for ceremonial purposes for people who are dead but it is never intended to be used for the interment of the deceased [18]. Examples from around the globe include: the one designed by Edwin Lutyens in Whitehall London, to commemorate the dead of both world wars and unveiled by the King on Armistice Day, the one in Regina, Saskatchewan, was unveiled on November 11, 1926. The Governor General of Canada, Lord Byng of Vimy, unveiled Montreal's Cenotaph in the Place du Canada, a part of Dominion Square, in 1921 [19].

\section{Conclusion}

Ecotourism management should be part of the social responsibilities of the Kogi State Government aimed at providing economic and social activities that support host communities. The tourists' attractions/heritage or relics in Lokoja are unique and are not available anywhere in the world.

\section{Recommendations}

There is a need for interesting and deliberate local and international publicity and marketing of the various tourist attractions in the state, particularly, those in Lokoja for a start.

The board will be in a better position to serve if the results and recommendations of the numerous academic and scientific studies conducted on tourism and related issues in the state are obtained by the board from source by visiting the institutions concerned and making demands for such. More importantly, the board could have a full-fledged research department or committee with the mandate for continuous research and recommendations made to the board to enhance productivity and quality service delivery. Such should either be answerable directly to the board's manager or the manager himself be the chairperson. Alternatively, the board could partner with university departments biased to 
tourism, to run researches that will serve the purpose of the board.

The mandate of Kogi State Tourism Board needs to be revisited to position it in the mainstream of current tourism trends in the world; they should be given the mandate and financial wherewithal; to help foster and promote the state's emerging tourism industry, to protect and promote Kogi State tourists centers and to help communities plan and develop recreational opportunities for local and international tourists.

As a matter of urgency, cable transportation from Tourism Board straight to the top of Mount Patti is needed to increase tourist patronage.

There is an urgent need for a functional airport with local and international wings in Kogi State to encourage both local and international tourist patronage.

Private investors are encouraged to take particular note of the recommendations, with a view to investing in this aspect of Nigeria.

Further research is needed as to how to implement the aforementioned recommendations.

\section{Conflicts of Interest}

The author declares no conflicts of interest regarding the publication of this paper.

\section{References}

[1] Muhanna, E. (2006) Sustainable Tourism Development and Environmental Management for Developing Countries. Problems and Perspectives in Management, 4, 2. https://businessperspectives.org/images/pdf/applications/publishing/templates/artic le/assets/519/PPM_EN_2006_02_Muhanna.pdf

[2] Groth, A. (2000) Sustainable Tourism and the Environment. Connect, 25, 1-2.

[3] Ogungbemi, B.A.F. (2005) Tourism Guide/Handbook of Kogi State. Fourth Edition, Kogi Hotels and Tourism Board, Lokoja, 127 p.

[4] Smith, S.S. (2004) The New International Webster's Comprehensive Dictionary of the English Language. Encyclopaedic Edition, Trident Press International, New Delhi, 1895 p.

[5] Margery, P. (2019) Frederick Lugard British Colonial Administrator. https://www.britannica.com/biography/Frederick-Lugard

[6] Travel, J. (2019) 83 Hotels in Lokoja-Best Lokoja Hotels. https://travel.jumia.com/en-gb/hotels/nigeria/lokoja/10000204

[7] Worldatlas (2015) Where Is Lokoja, Nigeria. http://www.worldatlas.com/af/ng/ko/where-is-lokoja.html

[8] Ukoje, J.E. (2016) Impacts of Rapid Urbanisation in the Urban Fringe of Lokoja, Nigeria. Journal of Geography and Regional Planning, 9, 185-194. https://doi.org/10.5897/jgrp2016.0591

[9] Lowe, J. and Soladoye, M.O. (1990) Some Changes and Corrections to Names of Nigerian Plants. Nigerian Journal of Botany, 3, 1-24.

[10] Daiziel, J.M. (1953) The Useful Plants of West Tropical Africa. Britain. 610 p.

[11] Hutchson, J. and Daiziel, J.M. (1954) Flora of West Tropical Africa. 2nd Edition, Vol. 11, Part 1. London. 544 p. 
[12] Okezie, I.A. and Agyakwa, C.W. (1998) A Hand Book of West African Weeds. 2nd Edition, International Institute of Tropical Agriculture, Ibadan, 565 p.

[13] Lowe, J. (1989) The Flora of Nigeria: 2nd Edition, Ibadan University Press, Grasses, $326 \mathrm{p}$.

[14] Mashana, N.R., Abbiw, D.K., Addae-Mensah, I., Adjanouhoun, E., Ahyi, M.R.A., Ekpere, J.A., Enow-Drock, E.G., Gbile, Z.O., Naomesi, G.K., Odei, M.A., Odunlami, H., Oteng-Yeboah, A.A., Sarpong, K., Sofowora, A. and Takie, A.N. (2000) Traditional Medicine and Pharmacopoeia. Contribution to the Revision of Ethno-Botanical and Floristic Studies in Ghana. Organization of African Unity/Scientific, Technical \& Research Commission, Accra, 920 p.

[15] About SCPRT (2012) South Carolina Department of Parks, Recreation \& Tourism. http://www.script.com/about-script/

[16] Powell, A. (2012) Tourism Board Offices to Undergo Improvements. http://www.gadsdentimes.com/article/

[17] Uliana, T. (2012) This Day Beyond Armed Forces Remembrance Day Celebration. http://en.wikipedia.org/wiki/armed_forces_day\#nigeria

[18] Merriam-Webster (2019) Cenotaph. https://www.merriam-webster.com/dictionary/cenotaph

[19] Trip Tern (1921) Cenotaph Montreal. https://www.google.com/search?q=\%5B19\%5D\%09Trip+Tern+(1921)+Cenotaph+Mon treal.\&tbm $=$ isch\&source=univ\&client $=$ firefox-b-d\&sa $=$ X\&ved $=2$ ahUKEwimkO2ZrMbj AhWEoVwKHffZCswQsAR6BAgJEAE\&biw=1366\&bih=654 